\title{
Upper Trishuli-2 Hydroelectric Project
}

\section{Introduction}

The proposed Upper Trishuli-2 Hydroelectric project of 102 MW capacity is situated $127 \mathrm{~km}$ north of Kathmandu, the capital city of Nepal, on the Trishuli River about $950 \mathrm{~m}$ downstream of Chilime Powerhouse (22 MW) in the Rasuwa District of Bagmati zone in the Central Development Region of Nepal. Proposed project is a Run-of-River (RoR) scheme aimed at utilizing the design discharge of $110 \mathrm{~m} 3 / \mathrm{s}$ to generate average annual hydro-based electric energy of 593 GWh. The catchment area at the proposed intake site is $4064 \mathrm{~km} 2$ and the rated head is $99.6 \mathrm{~m}$.

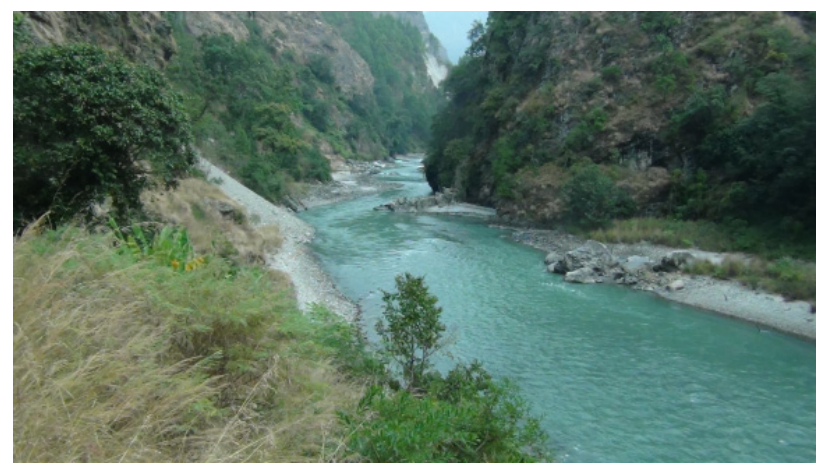

The project components are gated weir with side intakes, $3.65 \mathrm{~km}$ long and $7.0 \mathrm{~m}$ diameter headrace tunnel for water conveyance and underground powerhouse measuring $80.5 \mathrm{~m}$ long, $18.6 \mathrm{~m}$ wide and $45.1 \mathrm{~m}$ high to house 2 units of Francis turbines of $51 \mathrm{MW}$ capacity each. The power generated from the proposed project will be evacuated through a $22 \mathrm{~km}$ long $220 \mathrm{kV}$ transmission line to proposed Upper Trishuli 3 B Hub Substation of Nepal Electricity Authority.

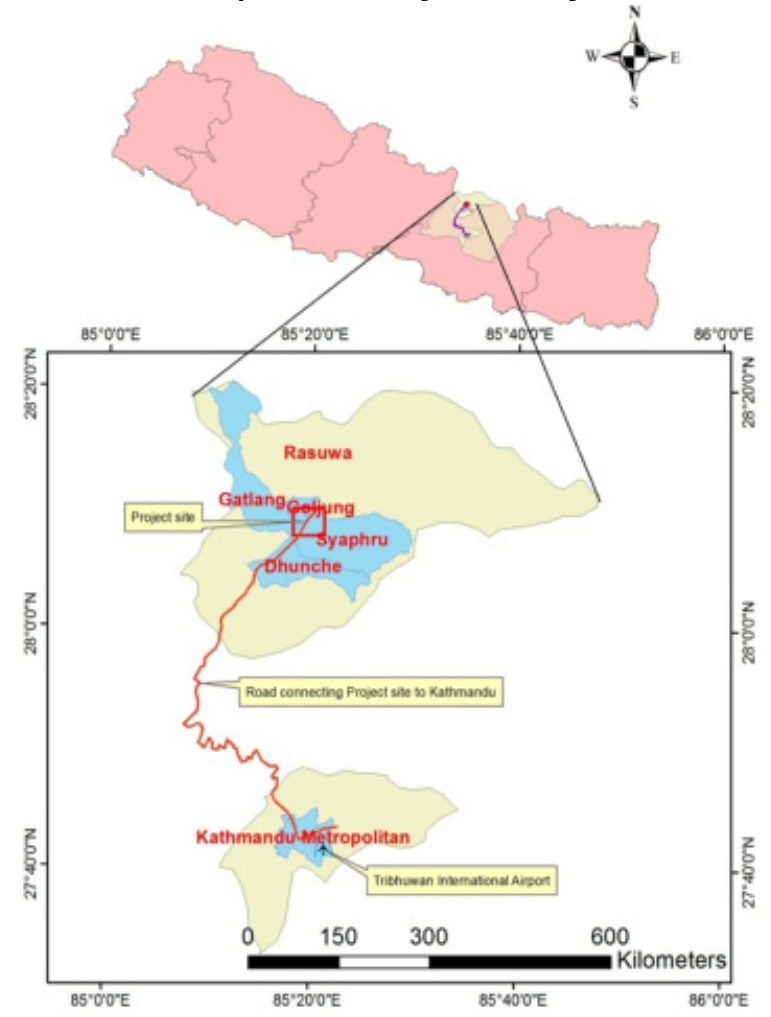

The project is being developed by Hydro China Corporation (HCC), China. The total estimated cost for the proposed project is 332.402 million US\$ with the construction period of 56 months and estimated investment recovery period of 14.4 years.

\section{Salient Features}

\section{Hydrology}

Total Catchment Area: $\quad 4064 \mathrm{~km}^{2}$

Design Discharge: $\quad 110 \mathrm{~m}^{3} / \mathrm{s}$

Design Flood: $\quad 4140 \mathrm{~m}^{3} / \mathrm{s}$

Installed Capacity: $\quad 102 \mathrm{MW}$

\section{Head}

Rated Head:

Energy Production

Average Annual Energy:

$99.6 \mathrm{~m}$

Energy Yield in Dry Season (Jan-April): 110 GWh

Energy Yield in Wet Season (May-Dec): 843GWh

\section{Wear}

Type:

Headrace - Tunnel

Type:

Length:

Diameter:

Tunnel

$3650 \mathrm{~m}$

Penstock

Inclined Shaft: Tunnel

Type:

Length:

200m

$4 \mathrm{~m}$

Diameter

Horizontal Pressure Tunnel:

Type:

Length:

Diameter:

Tunnel

$285 \mathrm{~m}$

$4 \mathrm{~m}$

\section{Powerhouse}

Type:

Length:

Width:

Height:

Underground

$80.5 \mathrm{~m}$

$18.6 \mathrm{~m}$

$45.1 \mathrm{~m}$

\section{Turbine}

Type:

Number:

Rated Output:

Francis

2

$51 \mathrm{MW}$

\section{Tailrace}

Type:

Tunnel

Length:

$400 \mathrm{~m}$

Note: Above mentioned dimensions of project components are subject to change.

\section{References}

Feasibility Study Report. Upper Trishuli-2 Hydroelectric Project, 2015

Environmental Impact Assessment of Upper Trishuli-2 Hydroelectric Project, 2016 